\title{
LÉKEK NÖVÉNYZETÉT MEGHATÁROZÓ TÉNYEZŐK VIZSGÁLATA KÜLÖNÖS TEKINTETTEL A MIKROKLÍMÁRA
}

\author{
Zagyvai Gergely¹, Eredics Attila², Csiszár Ágnes', Korda Márton'1, Lengyel Attila 3 ,4, \\ Tiborcz Viktor ${ }^{1}$ és Bartha Dénes ${ }^{1}$ \\ ${ }^{1}$ Soproni Egyetem, Növénytani és Természetvédelmi Intézet \\ ${ }^{2}$ Soproni Egyetem, Környezet- és Földtudományi Intézet \\ ${ }^{3}$ MTA Ökológiai Kutatóközpont, Ökológiai és Botanikai Intézet \\ ${ }^{4}$ Wroclawi Egyetem, Vegetációökológiai Tanszék (Lengyelország)
}

\begin{abstract}
Kivonat
Különböző magyarországi erdőállomány-típusokban kialakított, 12 lék mikroklíma mérőhálózatának adatelemzése alapján lineáris összefüggést találtunk a lékméret és egyes napi meteorológiai paraméterek között. Az állományban és a lékekben mért adatok összevetése az Országos Meteorológiai Szolgálat legközelebbi meteorológiai állomásának adataival szintén szabályos eltéréseket mutat. Az eredmények lehetőséget kínálnak egyes klímaparaméterek, pl. napi maximum és minimum becslésére különböző méretü lékekben és a környező állományokban, a szabványos meteorológiai megfigyelések alapján. 109 lék esetében vizsgáltuk, hogy a lékek jellemzői hogyan állnak összefüggésben a fajdiverzitással. Arra is választ kerestünk, mennyire érzékenyek az újulat fajai a lékeken belüli mikroklíma grádiensekre. A lékek korának és méretének hatása az egyes szociális magatartás típusok szerint eltérő, a lékek formája az újulat fajgazdagságára hat. A FAl (Forest Aridity Index) és a diverzitást jellemző változók között pozitív összefüggés mutatható ki. Az újulat léken belüli pozícióját vizsgálva megállapítható, hogy az összesített fajszám, egyedszám és effektív fajszám a lékek közepén a legmagasabb. A lékek üdébb részeit jellegzetes mezofil fafajok újulatának megjelenése indikálja.
\end{abstract}

Kulcsszavak: mesterséges lék, mikroklíma, ökológiai grádiens, újulat, növényi diverzitás.

\section{STUDIES ON FACTORS INFLUENCING FOREST GAP VEGETATION WITH SPECIAL ATTENTION TO THE MICROCLIMATE}

\begin{abstract}
Based on data from 12 microclimate measurement networks placed in different gaps of various forest stands in Hungary, linear correlation was found between the gap size and certain daily meteorological parameters. The comparison of the forest and gap data to the nearest state meteorological observatory also revealed systematic differences. These provide opportunity to estimate certain climatic parameters, e.g. daily maxima or minima in various sized gaps and the surrounding forest stand, based on standard meteorological observations. Relationship between attributes of 109 gaps and species diversity were analysed as well as indication of microclimatic gradient by regrowth species. Effect of gap age and size are different by social behaviour type. The shape of gaps affects the species richness of regrowth. Positive correlation was detected between Forest Aridity Index and diversity variables. The total number of species, individuals and effective numbers of regrowth species are highest in the centre of the gaps. Shady, moist areas of gaps are indicated by regrowth of typical mesophilous tree species.
\end{abstract}

Keywords: artificial gap, microclimate, ecological gradient, regrowth, plant diversity. 


\section{BEVEZETÉS}

Az elmúlt évtizedekben hazánkban is egyre kifejezettebbé vált az igény a társadalom részéről a folyamatos erdőboríás fenntartása mellett megvalósuló erdőgazdálkodás iránt. $A$ gyakorlati megvalósítást támogatva az elmúlt időszakban megélénkült a témával kapcsolatos kutatói aktivitás (Török 2000, Tobisch \& Standovár 2005, Standovár 2006, Csépányi 2008, Gálhidy 2008, Kenderes et al. 2007, 2008, Bartha \& Puskás 2013, Csiszár et al. 2014). A korábban vágásos üzemmódban kezelt, homogén, egykorú állományok heterogenitásának fokozása vagy örökerdőkké alakitása lékek nyitásával lehetséges. A Magyarországon üzemszerü léptékben bevezetett átalakító üzemmód lehetőséget adott a korábban részletesen tanulmányozott bükkösöktől eltérő erdőtársulás-csoportba tartozó állományok lékjeinek növényzeti és ökológiai vizsgálatára is.

A felújulás sikerét nagyban meghatározzák a lékek mikroklíma viszonyai, melyek elsősorban a lékek geometriai paramétereitől, a környező állomány jellemzőitől és a domborzattól függnek. A korábbi kutatások a besugárzás és felmelegedés szempontjából a lékméret (Minckler \& Woerheide, 1965, Collins \& Pickett, 1987) jelentőségét emelik ki, valamint eredményeket kínálnak a mikroklíma paraméterek léken belüli mintázatára vonatkozóan is (Collins et al., 1985, Eredics 2014).

Céljaink, melyek a felújulási viszonyokra, a növényzet összetételi és szerkezeti jellemzöire, valamint az ezeket meghatározó ökológiai tényezőkre (kiemelten a mikroklímára) koncentráltak a következő pontokban foglalhatók össze.

— Az eltérő méretű lékek mikroklíma adatai mennyiben különböznek az erdei és nyílt területeken létesített referenciapontok, valamint az országos méröhálózat adataitól.

- Hogyan befolyásolja a lékek területe, formája, a lékek nyitása óta eltelt idő és a klíma a lékek és szegélyük fajgazdagságát leíró változókat?

- A lékek fajszáma és fajsürüsége mennyire függ a táji adottságoktól, az eltérő klímától?

- A különböző szociális magatartástípusba tartozó fajok jelenlétükkel és tömegességükkel mennyire reagálnak a vizsgált magyarázó változókra?

— Az újulat fontosabb fafajai hogyan oszlanak el a jellemző mikroklíma grádiensek mentén?

\section{ANYAG ÉS MÓDSZER}

Vizsgálatainkat a terepi felvételezések idején átalakító és szálaló üzemmódban kezelt erdőrészletek területén kialakított mesterséges lékekben végeztük. A vizsgált lékek kora és mérete tág spektrumon változott. A gazdálkodással összefüggő előzményekből adódóan, szükebb táji környezetben mindkét változó egységesebb eloszlást mutatott. A mikroklíma mérések (12 lék) lékjeinek többsége átfed és növénytani vizsgálatok (109 lék) lékjeivel. A 
lékek növényzeti (újulat, cserje- és gyepszint) vizsgálatának eredményeit a mikroklíma mérésekkel összefüggésben értékeltük, annak érdekében, hogy az erdőgazdálkodási gyakorlatban is használható, természetvédelmi vonatkozásokkal is bíró eredményekkel járuljunk hozzá a folyamatos erdőborítás sikeres megvalósitásához

\section{Mikroklíma}

A mikroklímára vonatkozóan három helyszínen került sor részletes méréssorozatra. A lékek mikroklímájának vizsgálatát mindig lombos állapotban, összesen 12 különböző méretű lékben végeztük el a léghőmérséklet $(T)$ és relatív páratartalom $(R h)$ több ponton történő egyidejü mérésével (1. táblázat).

A lékekben egy É-D-i és egy K-Ny-i transzekt mentén 5 méterenként, a legnagyobb lékekben 10 méterenként mikroklíma mérő állomásokat helyeztünk el $1 \mathrm{~m}$ magasságban, melyek a $T$ és $R h$ értékeket 5 percenként rögzítették. A soproni méröhálózat a két lékben párhuzamosan üzemelt (17, ill. 20 mérési ponttal), a másik két helyszínen a 15 mérési pontból álló hálózatot 2-4 hét mérés után mindig újabb lékbe telepítettük. Mindhárom kísérleti terület közelében (max. távolság $500 \mathrm{~m}$ ) kijelöltünk egy nyílt területi referencia pontot, és a zárt állomány alatt egy erdei referencia pontot is, melyek végig egy helyben maradtak. A nyillt területi referencia pont Sopronban a Harkai legelön, Csörötneken egy felújitás alatt álló vágásterület szélén, Zánkán pedig egy szántóföldek közötti árokparton volt.

A lékek méretét legegyszerübben az átlagos lékátmérő és a famagasság hányadosával $\left(D_{a ́ t} / H\right)$ lehet jellemezni, de az átlagos lékméret megállapítása szabálytalan alakú lékeknél, illetve olyan esetekben, amikor a léken belül egy vagy több hagyásfa is található, meglehetősen bizonytalan. Ezért a lékméret számszerüsitésére az ekvivalens átmérő és a famagasság hányadosát $\left(D_{\text {ekv }} / H\right)$ alkalmaztuk. Az ekvivalens átmérő egy akkora szabályos kör átméröje, melynek területe megegyezik a szabálytalan alakú lék szabad (tehát hagyásfával sem borított) területével. Az elemzések során a $D_{\text {ekv }} / H$ mutató szorosabb korrelációt mutatott a meteorológiai paraméterek eloszlásával, mint a hagyományos $D_{a ́ t} / H$ mutató, ezért az öszszefüggéseket a $D_{\text {ekv }} / H$ mutató függvényében számszerüsítettük (1. táblázat).

A mérésekhez alkalmazott szenzorokat minden évben a mérések előtt és után is kalibráltuk, így az egyes érzékelők közötti maradék bizonytalanság $\pm 0,2{ }^{\circ} \mathrm{C}$, ill. $\pm 3 \%$ mértéküre csökkent. Az 5 perces időközű mérési adatsorokat hibaszürés és kalibrációs korrekció után 15 perces mozgóátlaggal simítottuk, majd minden mérési pontra napi statisztikákat (átlag, minimum, maximum, napi ingás) számítottunk.

Az Országos Meteorológiai Szolgálat (OMSZ) mérőhálózatának óránkénti adatai a NOAA online adatbázisából származnak (NOAA NCEI 2017), melyekből szintén napi statisztikákat számítottunk. A OMSZ referencia állomások lékekhez viszonyított adatait a 2. táblázat foglalja össze. 
1. táblázat: A mikroklíma-mérésekkel érintett lékek és föbb jellemzőik.

Table 1: Main parameters of gaps related to the microclimate measures.

\begin{tabular}{|c|c|c|c|c|c|c|c|c|c|}
\hline & $\begin{array}{l}\text { átmérō } \\
\text { É-D } \\
(\mathrm{m})\end{array}$ & $\begin{array}{l}\text { átmérő } \\
\text { K-Ny } \\
(\mathrm{m})\end{array}$ & $\begin{array}{l}\text { Átlagos át- } \\
\text { mérö / } \\
\text { Famagasság } \\
D_{\text {át } t / H}\end{array}$ & $\begin{array}{l}\text { Ekvivalens át- } \\
\text { mérö / } \\
\text { Famagasság } \\
D_{\text {ekv/H }}\end{array}$ & $\begin{array}{l}\text { Mérések } \\
\text { éve }\end{array}$ & Erdőrészlet & Állománytípus & Főfafajok & $\begin{array}{l}\text { Átlagos } \\
\text { magasság } \\
(\mathrm{m})\end{array}$ \\
\hline 1. & 20 & 20 & 1,00 & 1,09 & \multirow{2}{*}{2015} & \multirow{2}{*}{ Sopron $80 / C$} & \multirow{2}{*}{$\begin{array}{l}\text { gyertyános- } \\
\text { kocsánytalan } \\
\text { tölgyes }\end{array}$} & \multirow{2}{*}{ kocsánytalan tölgy } & \multirow{2}{*}{20} \\
\hline 2. & 30 & 30 & 1,50 & 1,58 & & & & & \\
\hline 3. & 20 & 20 & 0,80 & 0,75 & \multirow{5}{*}{2016} & \multirow{5}{*}{ Csörötnek 43/D } & \multirow{5}{*}{ fenyőelegyes tölgyes } & \multirow{5}{*}{$\begin{array}{l}\text { kocsánytalan tölgy, } \\
\text { kocsányos tölgy, } \\
\text { erdeifenyő, } \\
\text { bükk }\end{array}$} & \multirow{5}{*}{25} \\
\hline 4. & 20 & 40 & 1,20 & 1,07 & & & & & \\
\hline 5. & 10 & 20 & 0,60 & 0,48 & & & & & \\
\hline 6. & 9 & 8 & 0,34 & 0,32 & & & & & \\
\hline 7. & 25 & 50 & 1,50 & 1,35 & & & & & \\
\hline 8. & 20 & 15 & 0,88 & 0,69 & \multirow{5}{*}{2017} & Zánka 1/B & $\begin{array}{c}\text { cseres-kocsánytalan } \\
\text { tölgyes }\end{array}$ & $\begin{array}{c}\text { kocsánytalan tölgy, } \\
\text { csertölgy }\end{array}$ & 20 \\
\hline 9. & 20 & 15 & 0,97 & 0,94 & & \multirow{4}{*}{ Zánka 15/A } & \multirow{4}{*}{ cseres } & \multirow{4}{*}{$\begin{array}{l}\text { csertölgy, } \\
\text { mezei juhar }\end{array}$} & \multirow{4}{*}{18} \\
\hline 10. & 25 & 15 & 1,11 & 0,89 & & & & & \\
\hline 11. & 27 & 15 & 1,17 & 1,05 & & & & & \\
\hline 12. & 14 & 8 & 0,61 & 0,50 & & & & & \\
\hline
\end{tabular}


2. táblázat: A referenciaként használt OMSZ meteorológiai állomások lékekhez viszonyított helyzetének adatai.

Table 2: Position data of the nearest state meteorological observatory (OMSZ) compared to the studied gaps.

\begin{tabular}{|c|c|c|c|}
\hline \multirow{2}{*}{ Lékek helye } & Helye & $\begin{array}{c}\text { Távolsága } \\
(\mathbf{k m})\end{array}$ & $\begin{array}{c}\text { T.sz.f. magasság } \\
\text { különbség (m) }\end{array}$ \\
\cline { 2 - 4 } & Sopron, Kurucdomb & 3,4 & -50 \\
\hline Sopron 80/C & Szentgotthárd-Farkasfa & 3,5 & 3 \\
\hline Csörötnek 43/D & állomás & 90 \\
\hline Zánka 1/B, 15/A & Veszprém-Szentkirályszabadja & 33,5 & 9 \\
\hline
\end{tabular}

Az egyes lékekben a mérések 11-80 napon keresztül zajlottak, de a hosszabb adatsorokból csak azokat a napokat használtuk fel a lékek jellemzésére, melyek időjárása az OMSZ referencia állomás adatai alapján hasonló tartományban mozgott, vagyis: a mérési periódus legalacsonyabb napi minimum hömérséklete $8-13^{\circ} \mathrm{C}$, a legmagasabb napi maximum hőmérséklete $28-33^{\circ} \mathrm{C}$, a teljes periódus átlaghőmérséklete pedig a $17-24{ }^{\circ} \mathrm{C}$ tartományon belül változott.

Az értékelés során nem közvetlenül a mért meteorológiai paramétereket $(T, R h)$ elemeztük, hanem azok eltérését (különbségét) az erdei referencia ponttól $(\Delta T, \Delta R h)$, vagyis azt vizsgáltuk, hogy a lékek pontjai, valamint a nyiltt területi referencia és az OMSZ referencia pontok mennyivel melegebbek/hidegebbek, ill. szárazabbak/párásabbak az erdei referenciánál (zárt erdőnél). Az összehasonlításoknál a lék pontjaiba beleszámítottuk a lék peremén elhelyezkedő pontokat és a lékben lévő hagyásfák alatti pontokat is.

Az adott meteorológiai paraméter $(P)$ eltérésének nagyságát $(\Delta P)$ a lékméret függvényében egyszerü lineáris regresszióval közelítettük, ami a vizsgált lékméret tartományban $\left(0,3 \leq D_{\text {ekv }} / H \leq 1,7\right)$ jó közelítésnek bizonyult:

$$
\Delta P=a \frac{D_{e k v}}{H}+b
$$

ahol $\triangle P$ a meteorológiai tényező ( $T$ vagy $R h$ ) eltérése az erdei referencia ponttól, a és $b$ pedig lineáris regressziós paraméterek.

Az adatfeldolgozást és értékelést Scilab 5.4.1 (Scilab Enterprises 2012) környezetben irt, saját fejlesztésủ algoritmusokkal és programokkal végeztük.

\section{Lékek növényzete}

109 db lék növényzetét vizsgáltuk, melyek Bejcgyertyános, Budapest (II. kerület), Csörötnek, Fenyőfö, Pécsely, Sopron, Vállus, Vép, Zánka községhatárokban helyezkedtek el. A lékeket 2-13 évvel a felvételezésüket megelőzően alakították ki. Erdőtársulás-csoport szerint 
cseres-kocsánytalan tölgyesben, gyertyános-kocsánytalan tölgyesben, fenyőelegyes tölgyesben, mész- és melegkedvelő tölgyesben és sziklaerdőben dolgoztunk. Az egyes lékek felvételezését 2013 nyarán egy alkalommal, két térbeli léptékben végeztük: először rögzítettük a lék paramétereit és az egyes növényfajok boritását a lék egészére vonatkozóan, majd a lék átlóira fektetett mintakörökből álló transzektek segítségével részletes cönológiai felvételeket készítettünk. Az adatrögzítés során a cserje-, gyep- és újulati szinteket különkülön vizsgáltuk. A lékeken belüli mintakörökben az újulat fajonkénti egyedszámát és magasságát szintén rögzítettük. $A z$ adatok kiértékelése során minden mintaléket tartalmazó erdőrészletre lekérdeztük a terület klimatikus adottságait jellemző erdészeti aszályossági index (FAl) értékét (Führer et al. 2011).

A lékek összehasonlító vizsgálata során Spearman-féle rangkorrelációs tesztekkel megvizsgáltuk, hogy a lékek kora, területe, az erdőrészlet FAI indexe és a lék alakját jellemző lékindex hogyan áll összefüggésben a cserje- és gyepszint teljes fajszámával, fajsürüségével (mintakörönkénti átlagos fajszámával), egyenletességével, az újulat egyed- és fajsürüségével, valamint az újulat magasságával. Az utóbb felsorolt függő változókat a lék tényleges területére és a lék szegélyére vonatkozóan is vizsgáltuk. A lék és a szegély fajsürüsége korrelálhat egymással, hiszen (legalább részben) azonos regionális fajkészletből „táplálkoznak": fajgazdag tájban a lékek és a szegélyek is gazdagabbak, míg fajszegény tájban mindketten szegényebbek lehetnek (Pärtel et al. 1996). Fontos többletinformációt rejthet azonban a lék fajsürüségének a regionális fajkészlettől független komponense, vagyis a táji léptékü fajgazdagság alapján várt fajsűrűségtől való eltérés mértéke. Mivel a regionális fajkészlet méretére vonatkozóan nem végeztünk felmérést, helyette a szegély fajsürűségét használjuk közelítő értékként. A keresett eltérést leíró változó pedig nem más, mint annak az általános lineáris modellnek a reziduálisa, amelyben a függő változó a lék fajsürüsége, a magyarázó változó pedig a szegély fajsürüsége. Az összefüggések szignifikanciáját permutációs tesztekkel állapítottuk meg. A teszteket elvégeztük a teljes fajkészletre és külön-külön szociális magatartás típusokra bontva is (Borhidi 1993).

A lékeken belüli előfordulási mintázatok kiértékelése során a léken belüli mintakörök sorszámait 0 és 1 közé standardizáltuk úgy, hogy a transzekt északi és keleti végén lévő mintakörök értéke 0 lett, a déli és nyugati végén lévőké 1, a középen lévőé 0,5 . Ezzel a lékméret hatásától függetlenítettük az elemzést. A keleti és a nyugati oldalt elvileg azonos ideig süti a nap (amennyiben a kitettségnek nincs jelentős módosító hatása), viszont a nyugati oldalt érő délelőtti napsütés hatása gyengébb, mivel az éjszakai harmat még üdébb mikroklímát biztosít a növényeknek. A korábbi vizsgálatok szerint a léken belüli szárazság-grádiens az ÉK-DNy irány mentén változik a legerősebben. A maximális hőmérsékletek és minimális páratartalmak a lék középpontjához képest É-ÉK-i irányban eltolódva jelentkeznek (pl. Collins et al., 1985, Eredics 2014) . A standardizált pozíció függvényében kvantilis regresszió (Cade \& Noon 2003) segítségével modelleztük egyedi fajok, areatípusok, valamint a teljes fajszám, a teljes egyedszám és az effektív fajszám (a Shannon-féle entrópia exponense; Hill 1973) változását. 


\section{EREDMÉNYEK ÉS MEGVITATÁSUK}

\section{Mikroklíma}

A napi átlaghőmérsékletek átlagának vizsgálatakor a különböző lékméretek hatása alig kimutatható, csak gyenge pozitív korreláció fedezhető fel az adatokban. A zárt állományhoz képest a lékek pontjainak átlaghőmérséklete a soproni és csörötneki lékek esetében alig 0,0-0,2 ${ }^{\circ} \mathrm{C}$-kal magasabb, de a zánkai száraz tölgyesekben is csak $0,3-0,8^{\circ} \mathrm{C}$-kal magasabb. A nyilt területi referencia pont napi átlaghömérséklete $0,5-0,8^{\circ} \mathrm{C}-\mathrm{kal}$, az OMSZ referencia pont napi átlaghőmérséklete pedig $0,1-0,2^{\circ} \mathrm{C}$-kal volt magasabb a zárt állománynál. Ez utóbbi eredményt úgy is megfogalmazhatjuk, hogy a zárt erdőallományok napi átlaghőmérséklete átlagosan $0,2^{\circ} \mathrm{C}$-kal alacsonyabb a legközelebbi OMSZ mérőállomás napi átlaghömérsékleténél.

Eredményeink szerint a lékek legmelegebb pontjainak napi maximumhőmérséklete ( $T_{\text {napi }}$ max) esetében a lékmérettől való függés jól kimutatható, ami szinkronban van az előzetes várakozásokkal, melyek szerint a besugárzás mértéke és az ebből adódó felmelegedés is arányos a lék méretével (Minckler \& Woerheide, 1965, Collins \& Pickett, 1987). A különböző állományok között felfedezhető némi szisztematikus eltérés, de az összes léket tekintve is magas határozottsági fokú összefüggést kapunk, az (1) egyenlet alapján konkrét értékekkel:

$$
\left(\Delta\left(T_{\text {napimax }}\right)\right)_{\max }=6,13 \frac{D_{e k v}}{H}-1,43 \quad R^{2}=0,78
$$

ahol $\left(\Delta\left(T_{\text {napi max }}\right)\right)_{\max }$ a lékek legmelegebb pontján a mérési időszakban mért legmagasabb napi maximumhőmérséklet eltérés a zárt állománytól. A (2) egyenlet tehát azt adja meg, hogy a lékek legmelegebb pontja maximálisan hány fokkal lehet melegebb a zárt erdőnél.

A nyílt területek legnagyobb napi maximumhőmérséklete $6-8^{\circ} \mathrm{C}-\mathrm{kal}$, az OMSZ állomásoké pedig $3-4^{\circ} \mathrm{C}$-kal magasabb a zárt állományoknál. Ebből az is látszik, hogy a nagyobb lékekben még a nyilt területnél is magasabb hőmérsékletek alakulhatnak ki, ami a szél korlátozott keverő hatásával magyarázható: a lékekben könnyebben megül a forró levegő (hőkatlan), míg a nyilt területen már egy kisebb szellő is hatékonyabban hüti a felszínt.

Az előző összefüggések a lékek és a zárt állomány között a mérési időszakban valaha is észlelt legnagyobb hömérsékleti különbséget írták le, de ilyen viszonylag ritkán fordul elő. Ha a napi maximum hőmérsékletek eltérésének nem az abszolút maximumát tekintjük, mint az elöbb, hanem az átlagát, akkor arról kapunk képet, hogy átlagosan mennyivel melegebb a lékek legmelegebb pontja. A (3) egyenlet tehát a rendszeresen ismétlődő „hőterhelés" nagyságát jellemzi a lékekben:

$$
\left(\Delta\left(T_{\text {napimax }}\right)\right)_{\text {atlag }}=3,35 \frac{D_{e k v}}{H}-0,5 \quad R^{2}=0,61
$$


ahol $\left(\Delta\left(T_{\text {napi max }}\right)\right)$ átlag a lékek legmelegebb pontján a mérési időszakban mért napi maximumhőmérsékletek átlagának eltérése a zárt állomány napi maximumhőmérsékleteinek átlagától. A (3) egyenlet tehát azt adja meg, hogy a lékek legmelegebb pontja átlagosan hány fokkal melegebb a zárt erdőnél.

A nyilt területek átlagos napi maximumhőmérséklete $5-6^{\circ} \mathrm{C}-\mathrm{kal}$, az OMSZ állomásoké pedig $2-3^{\circ} \mathrm{C}$-kal magasabb a zárt állományoknál. Ezek alapján megállapítható, hogy a napi maximumhőmérsékletek átlagos eltérése a zárt erdőtől a nyilt területen a legnagyobb, és nem a lékekben.

A relatív páratartalom értékeiről megállapítható, hogy a várakozásoknak megfelelően a hőmérséklettel fordítottan arányosan változnak, vagyis a magasabb hőmérsékletekhez alacsonyabb relatív páratartalmak tartoznak. Az adatok elemzésével kapott összefüggéseket a 3. táblázat foglalja össze. Azokban az esetekben, ahol a lékek pontjaira a lékméret függvényében nem lehetett magas határozottsági fokú összefüggést felírni, illetve az adott változó értéke nem függ a lék méretétöl, ott a különbséget egy átlagos konstanssal és a 90\%-os konfidencia intervallum feltüntetésével jellemeztük.

3. táblázat. A különböző meteorológiai változók átlagos és maximális eltérése az erdei referencia ponttól: az

(1) egyenlet szerinti lineáris regresszió a és b paramétere, ill. $R^{2}$ határozottsági foka, vagy átlagos eltérés konstansként $\pm 90 \%$-os konfidencia intervallum. Az eredmények $0,3 \leq D_{\text {ekv }} / H \leq 1,7$ méretü lékekben, tipikus nyári napok esetén igazak: $8^{\circ} \mathrm{C} \leq T_{\min } \leq 13^{\circ} \mathrm{C}, 17^{\circ} \mathrm{C} \leq T_{\text {átl }} \leq 24^{\circ} \mathrm{C}, 28^{\circ} \mathrm{C} \leq T_{\max } \leq 33^{\circ} \mathrm{C}$.

(OMSZ referencia napi hőmérséklet)

Table 3: Average and maximum differences of the meteorological variables compared to the forest stand reference point: $a$ and $b$ parameters and $R^{2}$ of linear regression according to equation (1), or average difference as constant $\pm 90 \%$ confidence interval. The results are valid if gap size is $0,3 \leq D_{\text {ekv }} / H \leq 1,7$, on typical summer days, when $8^{\circ} \mathrm{C} \leq T_{\min } \leq 13^{\circ} \mathrm{C}, 17^{\circ} \mathrm{C} \leq T_{\text {mean }} \leq 24^{\circ} \mathrm{C}, 28^{\circ} \mathrm{C} \leq T_{\max } \leq 33^{\circ} \mathrm{C}$.

(OMSZ reference daily temperature)

\begin{tabular}{|c|c|c|c|c|c|c|}
\hline Meteorológiai változó & \multicolumn{4}{|c|}{ Lékek pontjai } & \multirow{3}{*}{$\begin{array}{c}\text { Nyílt ref. } \\
\text { kons- } \\
\text { tans- } \\
\text { ként } \\
{ }^{\circ} \mathrm{C} \text { vagy } \\
\%\end{array}$} & \multirow{3}{*}{$\begin{array}{c}\begin{array}{c}\text { OMSZ } \\
\text { ref. }\end{array} \\
\text { kons- } \\
\text { tans- } \\
\text { ként } \\
{ }^{\circ} \mathrm{C} \text { vagy } \\
\%\end{array}$} \\
\hline eltérése a zárt állománytól & \multicolumn{3}{|c|}{$\begin{array}{l}\text { lékméret függvényében } \\
\text { az (1) egyenlet szerint }\end{array}$} & $\begin{array}{l}\text { kons- } \\
\text { tans- } \\
\text { ként }\end{array}$ & & \\
\hline & a & $b$ & $R^{2}$ & $\begin{array}{c}{ }^{\circ} \mathrm{C} \text { vagy } \\
\%\end{array}$ & & \\
\hline \multicolumn{7}{|c|}{ maximális eltérés } \\
\hline napi átlaghőmérséklet & & & & $0,5 \pm 0,2$ & $0,8 \pm 0,3$ & $0,3 \pm 0,2$ \\
\hline napi maximumhőmérséklet & 6,13 & $-1,43$ & 0,78 & & $6,7 \pm 1,3$ & $3,4 \pm 0,9$ \\
\hline napi maximális hőingás & 6,69 & $-1,76$ & 0,74 & & $9,1 \pm 2,7$ & $3,6 \pm 1,7$ \\
\hline napi minimális páratartalom & $-12,53$ & 1,95 & 0,69 & & $-22 \pm 15$ & $-25 \pm 23$ \\
\hline \multicolumn{7}{|c|}{ átlagos eltérés } \\
\hline napi átlaghőmérséklet & & & & $0,3 \pm 0,1$ & $0,7 \pm 0,4$ & $0,2 \pm 0,1$ \\
\hline napi maximumhőmérséklet & 3,35 & $-0,50$ & 0,61 & & $5,7 \pm 0,7$ & $2,5 \pm 0,9$ \\
\hline napi maximális hőingás & 3,46 & $-0,49$ & 0,64 & & $8,3 \pm 1,8$ & $3,2 \pm 2,3$ \\
\hline napi minimális páratartalom & $-6,76$ & 0,07 & 0,49 & & $-17 \pm 10$ & $-17 \pm 9$ \\
\hline
\end{tabular}




\section{Lékek növényzete}

A lékek összehasonlító elemzése során vizsgáltuk a magyarázó változók (terület, lékindex, kor, FAl) és a fajdiverzitására vonatkozó függő változók összefüggéseit az összes felvett fajra vonatkozóan. Magas korrelációs értékeket kaptunk a lék és szegélyének fajsűrüsége, fajszáma, valamint az erdészeti aszályossági index (FAl) között. A léken belüli fajsürüség reziduálisa és a FAl között azonban nem áll fenn szignifikáns összefüggés, ami arra utal, hogy magasabb fajsürüség és fajszám a nyíltabb, fényben gazdag, szárazabb erdők sajátja, tehát inkább táji adottság, mint a lékek nyitásával összefüggő sajátosság (4. táblázat).

4. táblázat: A lékek magyarázó és függő változóinak korrelációs mátrixa az összes fajra vonatkozóan ("+++" vagy "---": $p<0,001$, "++" vagy "--": $p<0,01$, "+" vagy "-": $p<0,05$, "=": nincs hatás).

Table 4: Correlation matrix of independent and dependent variables for all species ("+++" or "---": $p<0,001$, "++" or "--": $p<0,01$, "+" or "-": $p<0,05$, "=": non-effect).

\begin{tabular}{|l|c|c|c|c|}
\hline & Terület & Lékindex & Kor & FAI \\
\hline Cserje- és gyepszintben a lék teljes fajszáma & $=$ & $=$ & $=$ & +++ \\
\hline Cserje- és gyepszintben a lék fajsürüsége & $=$ & + & $=$ & +++ \\
\hline Cserje- és gyepszintben a szegély fajsürüsége & $=$ & $=$ & $=$ & +++ \\
\hline Cserje- és gyepszintben a lék egyenletessége & $=$ & $=$ & +++ & +++ \\
\hline Cserje- és gyepszintben a szegély egyenletessége & $=$ & $=$ & +++ & $=$ \\
\hline Cserje- és gyepszintben a fajsürüség reziduálisa & $=$ & ++ & $=$ & $=$ \\
\hline Az újulat fajsürüsége a lékben & $=$ & ++ & $=$ & +++ \\
\hline Az újulat fajsürüsége a szegélyben & $=$ & + & $=$ & +++ \\
\hline Az újulat egyedsürűsége a lékben & + & $=$ & $=$ & $=$ \\
\hline Az újulat egyedsürüsége a szegélyben & $=$ & $=$ & $=$ & $=$ \\
\hline Az újulat magassága a lékben & $=$ & + & +++ & ++ \\
\hline Az újulat magassága a szegélyben & $=$ & $=$ & ++ & +++ \\
\hline
\end{tabular}

Az összes fajt vizsgálva megállapítható, hogy az egyenletesség értéke a lékek korának elörehaladtával a lékekben és közvetlen szegélyükben egyaránt nő. A lék formájának kiegyenlítettsége közepesen erős pozitív összefüggést mutat az újulat fajsürüségével (mintaköreinek fajszámával). Valószínüsíthetően a körhöz hasonló lékek adottságai kedveznek az erdőállományok állományalkotó fafajai mellett az elegyfajok nagyobb számú megjelenésének is.

A fentihez hasonló korrelációs vizsgálatot úgy is elvégeztük, hogy a teljes fajlistát szociális magatartás típusok (SBT) szerint csoportositottuk, melyek közül a legfontosabb eredményeket emeljük ki. A természetes kompetitorok (C) fajszámával és fajsürüségével a lék 
nyitása óta eltelt időtartam mutat erős összefüggést a cserje- és gyepszintre vonatkozóan. A kor összefüggése a vonatkozó reziduális értékkel szintén erős, így megállapítható, hogy a jelenség a lékeket a táji sajátosságoktól függetlenül jellemzi (pl. Carex pilosa, Luzula luzuloides, Stellaria holostea, Poa nemoralis, Fagus sylvatica, Fraxinus excelsior, Fraxinus ornus, Quercus petraea, Quercus robur, Quercus cerris, Tilia platyphyllos).

A szárazabb klímájú lékek és szegélyeik egyaránt gazdagabbak generalista fajokban (G) a vizsgált növényzeti szintek mindegyikében, mint a nedvesebb állományok mintaterületei. Az újulat esetében az erős pozitív összefüggés az újulat egyedszámára és magassági értékeire is vonatkozik, nemcsak az erdészeti aszályossági index (FAI), hanem a lék korának függvényében is (pl.: Ajuga reptans, Brachypodium sylvaticum, Clinopodium vulgare, Acer campestre, Acer platanoides, Tilia cordata, Ulmus minor, Sorbus torminalis, Pyrus pyraster).

Eredményeink szerint a specialista fajoknak (S) kedvez a dinamikai folyamatok léknyitást követő iránya, a specialisták nagyobb fajszámban az idősebb lékekben fordulnak elő (pl.: Lathyrus vernus, Galium rotundifolium, Dryopteris carthusiana, Cotinus coggygria, Acer pseudoplatanus, Acer tataricum, Cerasus avium, Sorbus domestica, Padus avium). E megállapitás természetesen a vizsgált lékek korának léptékére (2-13 év) vonatkozik, a felújulás ciklusának ezt követő, nagyobbik szakaszáról nincsenek információink.

A léknyitással járó bolygatáshoz erősen kötődő honos gyomfajok (W) és különösen a ruderális kompetitorok (RC) fajszámra vonatkozó változói a lék korával negatív összefüggést körvonalaznak, tehát az idő elöre haladtával „kikopnak” a lékekből, miközben a természetes kompetitorok és specialisták fajszáma növekszik. A ruderális kompetitorok (RC) fajszáma és fajsürüsége egyaránt magasabb a nagyobb területü lékekben (W - pl.: Ballota nigra, Chelidonium majus, Galium aparine, Lamium purpureum, Sambucus nigra; RC - pl.: Calamagrostis epigeios, Chenopodium album, Taraxacum officinale, Bromus sterilis).

A magyarázó változók hatását a szociális magatartás-típusok csoporttömegére vonatkozóan is vizsgáltuk. A szárazabb klímájú erdőállományokban nyitott lékekben a természetes kompetitorok $(C)$, generalisták $(G)$, specialisták $(S)$ és idegenhonos gyomok $(A)$ nagyobb borításértékekkel vannak jelen. Nedvesebb klímában a zavarástürő fajok (DT) szerepe kiemelkedö. A zavarástürök (DT) tömege az idősebb lékekben növekszik, hasonlóan az idegenhonos gyomokhoz (A). A ruderális kompetítorok (RC) definíciójából logikusan magyarázható az az összefüggés, hogy a típusba tartozó fajok a nagyobb és körhöz hasonló alakú lékekben találják meg azokat a bolygatott felszíneket, melyek kedveznek nagyobb mértékü terjedésüknek (5. táblázat).

A vizsgálat során arra is választ kerestünk, hogyan indikálhatja az újulat a lékeken belüli mikroklíma grádienseket. A tesztek eredményei szerint a fajszám, az egyedszám és az effektív fajszám kicsivel magasabb volt a lék közepén, mint a szélein, és valamivel magasabb a déli és nyugati részen, mint az északi és keleti részen. Unimodális válaszgörbét mutatott a közönséges nyír (Betula pendula), a csertölgy (Quercus cerris), a kocsánytalan tölgy (Quercus petraea) és a közönséges gyertyán (Carpinus betulus). A fehér akác (Robinia pseudoacacia) egyedszáma a lék széleihez közel, de inkább az északi és keleti oldalon ért el 
magasabb értékeket. Jobbára a lék hüvösebb, déli és nyugati oldalát preferálta a közönséges bükk (Fagus sylvatica), a hegyi juhar (Acer pseudoplatanus) és a magas kőris (Fraxinus excelsior) (1. ábra). Az adventív fajok csoportja a lékek északi és keleti részén magasabb részesedést mutattak, ami gyakorlatilag az akác mintázatát tükrözi.

5. táblázat: A lékek magyarázó változóinak és a szociális magatartás típusok csoporttömeg értékeinek korrelációs mátrixa az összes fajra vonatkozóan ("+++" vagy "---": $p<0.001$, "++" vagy "--": $p<0.01$, "+" vagy "-": $p<0.05$, "=": nincs hatás, ".": nem végezhetö el az összehasonlitás).

Table 5: Correlation matrix of variables and dominance proportion of social behaviour types for all species ("+++" or "---": $p<0,001$, "++" or "--": $p<0,01$,

"+" or "-": $p<0,05, "="$ : no significant correlation).

\begin{tabular}{|l|c|c|c|c|}
\hline & Terület & Lékindex & Kor & FAI \\
\hline C - természetes kompetitorok & $=$ & $=$ & - & +++ \\
\hline G - generalisták, tág ökológiájú stressztürök & $=$ & $=$ & $=$ & +++ \\
\hline S - specialisták, szük ökológiájú stressztürök & $=$ & $=$ & $=$ & +++ \\
\hline DT - zavarástűrő növények & $=$ & $=$ & +++ & --- \\
\hline AC - tájidegen, agresszív kompetitorok & - & $=$ & $=$ & $=$ \\
\hline W - honos gyomfajok & $=$ & $=$ & $=$ & $=$ \\
\hline RC - a honos flóra ruderális kompetitorai & ++ & ++ & $=$ & $=$ \\
\hline Su - unikális specialisták & $=$ & $=$ & -- & - \\
\hline I - meghonosodott és kivadult haszonnövények & $=$ & $=$ & + & $=$ \\
\hline A - adventív elemek & - & - & +++ & +++ \\
\hline NP - természetes pionírok & $=$ & $=$ & $=$ & $=$ \\
\hline
\end{tabular}
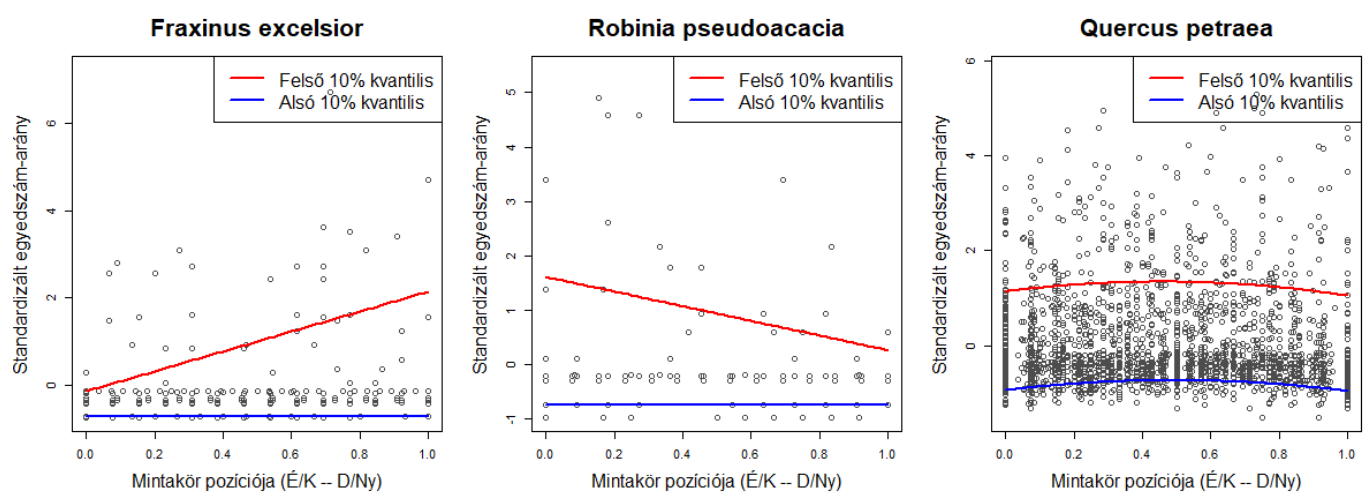

1. ábra: Három jellegzetes élőhelyigényű faj standardizált egyedszámának eloszlása a léken belüli pozíció függvényében, $10 \%$ és $90 \%$-os kvantilisre illesztett regresszióval.

Figure1: Distribution of number of individuals after standardization of three tree species representing different habitat types, along position in gap using quantile (10 and 90\%) regression. 


\section{ÖSSZEFOGLALÁS ÉS KÖVETKEZTETÉSEK}

A körhöz hasonló alakú lékekben a legmelegebb részeket (É-i és K-i oldal) a nap pályája határozta meg az elméleti várakozásoknak megfelelően. A lékek újulatának elemzése során a mezofil bükk és tipikus bükkös elegyfajként a hegyi juhar, valamint a magas köris jól indikálták a transzektek ellenkező oldalán elhelyezkedő árnyékosabb, üdébb területeket.

A többi fafaj esetében az újulat lékeken belüli diverzitási mutatói és a legtöbb fafaj csemeteszáma a lékek közepén éri el maximumát.

A szabálytalan alakú és/vagy hagyásfákkal tarkított lékekben a meteorológiai változók eloszlása jobb korrelációt mutatott a $D_{\text {ekv }} / H$ aránnyal, mint a $D_{\text {att }} / H$ aránnyal, vagyis a mikroklíma alakulása pontosabban becsülhető a lékek nyiltt felszínének nagysága alapján, mint a két léktengely átlagos átmérője alapján.

A körhöz hasonló kiegyenlített lékforma pozitívan befolyásolja az újulat fajsürüségét, ami összefügghet azzal, hogy ezekben a lékekben a léknyitás mikroklímát módosító hatása fokozottabban érvényesül. Az egységnyi területre jutó magasabb fajszám a lékek újulatában esélyt ad arra, hogy elegyesebbé váljon az erdőállomány. Az újulat magasabb fajdiverzitása a vizsgált korai felújulási stádiumokban szükséges, de nem elégséges feltétele az állomány ilyen irányú átalakulásának.

A zárt állomány mikroklímája a legkiegyenlítettebb. A nagyobb lékekben idönként még a nyílt területnél is magasabb hömérsékletek alakulhatnak ki (hökatlan), de az átlagos napi maximumhőmérsékletek a nagy nyilt területeken a legnagyobbak, és nem a lékekben. A relatív páratartalom minimális értékei a maximumhőmérséklettel összhangban, de azzal fordítottan arányosan változnak, ami fokozza a szélsőséges időjárási helyzetek párolgást kényszerítő (száríó) hatását. Ez a nagy lékméreteknél jelentkező fokozott szárító hatás kedvezötlenül befolyásolja a mezofil erdei növényfajok és fafajok újulatának életképességét. Az újulat érdekében minden esetben fontos a kielégítő fénymennyiséget biztosító ideális lékméret meghatározása, azzal azonban számolni kell, hogy a lék méretének növelésével a fényigényes ruderális kompetitor fajok száma és boritása egyaránt emelkedik.

Erdőművelési és természetvédelmi szempontból is pozitív eredmény, hogy a lékek korának növekedésével a felújulást is akadályozó ruderális és adventív kompetitorok és gyomfajok száma csökken, a természetközeli erdötársulásokra jellemző kompetitorok, generalisták és specialisták száma növekszik.

A háttérváltozóként használt erdészeti aszályossági index (FAl) és a diverzitást jellemző változók között pozitív összefüggés mutatható ki, mely elsősorban a klíma által befolyásolt táji különbségekre vezethető vissza, a szárazabb erdőtársulásokra jellemző magasabb szerkezeti (nyiltabb állományok) és fajdiverzitási jellemzőkkel hozható összefüggésbe 


\section{KÖSZÖNETNYILVÁNÍTÁS}

Szeretnénk köszönetet mondani a lékek, ill. a méröhálózat kialakításához nyújtott segítségért Köveskuti Zoltánnak és Schiffer Sándornak. A kutatást a VKSZ_12-1-2013-0034 „Agrárklíma 2" projekt támogatta.

\section{FELHASZNÁLT IRODALOM}

Bartha D. \& Puskás L. (eds) 2013: Silva naturalis Vol.1. Nyugat-magyarországi Egyetem Kiadó, Sopron.

Borhidi A.1993: A Magyar Flóra szociális magatartás típusai, természetességi és relatív ökológiai értékszámai. Janus Pannonius Tudományegyetem, Pécs.

Cade B.S. \& Noon B.R. 2003: A gentle introduction to quantile regression for ecologists. Frontiers in Ecology and the Environment 1(8): 412-420. DOI: 10.2307/3868138

Collins B.S., Dunneand K.P. \& Pickett S.T.A. 1985: Responses of forest herbs to canopy gaps. In: Pickett S.T.A. \& White P.S. (eds): The Ecology of Natural Disturbance and Patch Dynamics. Academic Press, Orlando, Florida, 217-234. DOI: 10.1016/b978-0-12-554520-4.50017-4

Collins B.S. \& Pickett S.T.A. 1987: Influence of canopy opening on the environment and herb-layer in a northern hardwoods forest. Vegetatio 70: 3-10. DOI: 10.1007/BF00040752

Csépányi P. 2008: A tölgy és folyamatos erdőborítás. Erdészeti Lapok 143(10): 294-297.

Csiszár Á., Korda M., Zagyvai G., Tiborcz V., Süle P., Šporčič D., et al. 2014: Gyertyános-tölgyesben kialakított lékek újulatának vizsgálata a Soproni-hegység területén. Erdészettudományi Közlemények 4(1): 23-35.

Eredics A. 2014: Mikroklimatikus viszonyok vizsgálata. In: Bartha D. \& Puskás L. (eds): Silva naturalis Vol. 6. Nyugat-magyarországi Egyetem Kiadó, Sopron, 10-34.

Führer E., Marosi Gy., Jagodics A. \& Juhász I. 2011: A klímaváltozás egy lehetséges hatása az erdőgazdálkodásban. Erdészettudományi Közlemények 1(1): 17-28.

Gálhidy L. 2008: Az aljnövényzet fajösszetételének és tömegességének változásai középhegységi bükkösök mesterséges és széldöntés nyomán létrejövő lékjeiben. Doktori értekezés. ELTE Növényrendszertani és Ökológiai Tanszék, Budapest.

Hill M.O. 1973: Diversity and evenness: a unifying notation and its consequences. Ecology 54(2): 427-432. DOI: $10.2307 / 1934352$

Kenderes K., Tímár G., Ódor P., Bartha D., Standovár T., Bodonczi L., et al. 2007: A természetvédelem hatása középhegységi erdeinkre. Természetvédelmi Közlemények 13: 69-80.

Kenderes K., Mihók B. \& Standovár T. 2008: Thirty years of gap dynamics in a central european beech forest reserve. Forestry 81(1): 111-123. DOI: 10.1093/forestry/cpn001

Minckler L.S. \& Woerheide J.D. 1965: Reproduction of hardwoods 10 years after cutting as affected by site and opening size. Journal of Forestry 63: 103-107.

Pärtel M., Zobel M., Zobel K. \& van der Maarel E. 1996. The species pool and its relation to species richness: Evidence from Estonian plant communities. Oikos 75(1): 111-117. DOI: 10.2307/3546327

Standovár T. 2006: Biológiai megfontolások az erdei életközösségek hatékony védelméhez. Magyar Tudomány 2006(6): 656-662. 
Tobisch T. \& Standovár T. 2005: A comparison of vegetation patterns in the tree and herb layers of a hardwood forest. Community Ecology 6(1): 29-37. DOI: 10.1556/comec.6.2005.1.4

Török A. 2000: Égtájorientált, erdőtípus-érzékeny természetes felújitási rendszer. Erdészeti Lapok 135: 170 171.

\section{On-line és digitális irodalom}

NOAA NCEI 2017: National Oceanic and Atmospheric Administration, National Centers for Environmental Information. Elérés: www.ncei.noaa.gov (letöltve: 2018. 08. 01.)

Scilab Enterprises 2012: Scilab: Free and Open Source software for numerical computation (OS, Version 5.XX) [Szoftver]. Elérés: www.scilab.org

Érkezett: 2018. május 4.

Közlésre elfogadva: 2018. május 31. 